\title{
A ação pastoral dos leigos missão, ministério e serviço
}

\author{
Orientador: Abimar Oliveira de Moraes \\ Mestrando: José Honorato Alves da Cunha \\ Área de Concentração: Teologia Sistemático-Pastoral \\ Linha de Pesquisa: Religião e Modernidade
}

A presente dissertação intitulada: A ação pastoral dos leigos: missão, ministério e serviço desenvolveu-se estimulada pela reflexão sobre a universalidade da comunhão que se traduz no dia-a-dia do conjunto dos cristãos. Comunhão essa que nos é apresentada em seus diversos aspectos, começando pelas definições, passando por sua essencialidade no que diz respeito à Igreja e chegando à sua condição de elemento integrador universal. Apresentamos essa comunhão como expressão da Santíssima Trindade. Essa é o elemento congregador que aqui torna irmãos os seguidores de Jesus dispersos por toda a terra. E este trabalho conta com o ministério comum a todos aqueles que abraçaram a fé. Nessa Igreja o protagonismo laical é importante não como suporte limitado à garantia de existência da instituição, mas como elemento constitutivo da mesma. A atividade pastoral é presença de Jesus, da Igreja e da humanidade nas vidas de pessoas que sofrem. Percebemos que a eclesiologia de comunhão nos ajudará a perceber que a Igreja está aberta ao diálogo e ao acolhimento indistinto de todas as pessoas com vistas a um mundo mais fraterno e justo. Oferecendo às pessoas uma concepção de realidade que abarca todos os seres humanos como iguais e, portanto, como seres que devem se apoiar mutuamente e não se destruírem em virtude de suas diferenças.

Palavras-chave: Leigos; Ministério; Ação Pastoral; Missão; Comunhão. 